\title{
Paracoccidioidomycosis: no genetic damage in human peripheral blood cells of patients assessed by single-cell gel (comet) assay
}

\author{
Paracoccidioidomicose: ausência de danos genéticos em células de sangue \\ periférico de pacientes avaliados pelo teste de células \\ individualizadas em gel (teste do cometa)
}

\author{
Renata Aparecida Martinez Antunes Ribeiro-Vieira ${ }^{1,2}$, Daniel Araki Ribeiro ${ }^{3}$, \\ Daisy Maria Favero Salvadori ${ }^{2}$ and Sílvio Alencar Marques ${ }^{1}$
}

\begin{abstract}
Paracoccidioidomycosis is a systemic fungal infection caused by Paracoccidioides brasiliensis. As infectious diseases can cause DNA damage, the authors aimed at analyzing DNA breakage in peripheral blood cells of patients with paracoccidioidomycosis by using the comet assay. The results suggested that paracoccidioidomycosis does not cause genotoxicity.
\end{abstract}

Key-words: Paracoccidioidomycosis. Paracoccidioides brasiliensis. Comet assay. Genotoxicity. DNA.

\section{RESUMO}

Paracoccidioidomicose é micose sistêmica causada pelo Paracoccidioides brasiliensis. Considerando que doenças infecciosas são capazes de induzir danos genéticos, o objetivou-se analisar quebras no DNA em células de sangue periférico de pacientes com paracoccidioidomicose utilizando o teste do cometa. Os resultados sugeriram que essa enfermidade não exerce genotoxicidade.

Palavras-chaves: Paracoccidioidomicose. Paracoccidioides brasiliensis. Teste do cometa. Genotoxicidade. DNA.

Paracoccidioidomycosis (PCM), a systemic fungal infection caused by Paracoccidioides brasiliensis, is highly prevalent in Latin America ${ }^{2}$. In countries such as Brazil, it is estimated that, in endemic areas, up to $10 \%$ of the population is infected, and the disease affects from one to three individuals in every 100,000 inhabitants ${ }^{8}$. The International Agency for Research on Cancer (IARC) acknowledges some pathogens as potential human carcinogens, such as the Human papilomavirus (HPV) 16 and 18, hepatitis-B (HBV) and hepatitis-C (HCV) viruses, Helicobacterpylori and Schistosoma haematobium ${ }^{6}$. Additionally, evidence shows other microorganisms, such as bacteria and helminthes as possibly involved in carcinogenesis 5 . As regards PCM, data on the likely association between Paracoccidioides brasiliensis and carcinogenesis are rare in the literature?. The identification of highly prevalent and infectious agents that are potentially damaging to genetic material is necessary, since it will enable the design of preventive measures as well as the development of strategies against high-risk infections.
Taking into account the relationship between DNA and carcinogenesis, the single-cell gel (comet) assay is a new, rapid, simple and easily performed biochemical technique for assessing damage to the DNA of eukaryotic cells ${ }^{13}$. The basic principle of the comet assay is the migration of DNA fragments on an agarose matrix under electrophoresis. When observed on the microscope, the cells show a comet appearance, with a head (nuclear region) and a tail containing DNA fragments that have migrated towards the anode. By considering the lack of genotoxicity evidence of in-vivo PCM, this study aimed at evaluating whether such disease, in its different development phases, can cause DNA damage, such as that detected by the comet assay.

Forty-four patients with a PCM diagnosis confirmed through the agent's identification by direct mycological examination or histological sections were evaluated. Thirteen of the individuals displayed active PCM (G1) and 11 were in clinical remission with positive serology according to the double immunodiffusion (DI) test (G2). The latter no longer presented clinical evidence of

\footnotetext{
1. Department of Dermatology and Radiotherapy, Botucatu School of Medicine, São Paulo State University, Botucatu, SP. 2. Department of Pathology, Botucatu School of Medicine, São Paulo State University, Botucatu, SP. 3. Department of Health Sciences, São Paulo Federal University, Santos, SP.

Address to: Dr. Sílvio Alencar Marques. Dept ${ }^{\circ}$ de Dermatologia e Radioterapia/FMB/UNESP. Distrito de Rubião Jr s/n, 18648-000 Botucatu, SP.

Tel: 55 14 3811-6015; Fax: $55143882-4922$

e-mail: smarques@fmb.unesp.br

Recebido em: 03/05/2006

Aceito em: 13/07/2007
} 
PCM - disease, but positive titles above the service's reference value (DI $\geq 1 / 4)$ still remained in quarterly evaluations. Furthermore, 20 individuals showed PCM in clinical remission and negative serology by the double immunodiffusion test, according to data from the 12 preceding months (G3 - negative control). The following were considered as exclusion criteria for participation in this study: history of smoking (more than 10 cigarettes a day), cancer, previous radiotherapy or chemotherapy, bacterial infection, high alcohol consumption and pregnancy. The study was approved of by the Committee of Ethics for Human Research of the Botucatu School of Medicine (UNESP) (Registration no. 1606/04) and by the National Committee of Research Ethics (CONEP) (Approval no 2153/2004).

The protocol used followed the methodology proposed by Tice et $\mathrm{a}^{13}$ with modifications. This technique can detect a broad spectrum of genetic lesions, including the breakage of single and double strands, alkaline-labile, and incomplete-repair sites ${ }^{12}$. These lesions can be fixed to the genetic material (after the cellular cycle), resulting in gene mutation.

A volume of $10 \mu \mathrm{l}$ of peripheral-blood cells was added to $120 \mu \mathrm{l}$ of $0.5 \%$ low-melting-point agarose at $37^{\circ} \mathrm{C}$ and deposited on histological slides previously covered with $1.5 \%$ normal-metingpoint agarose in duplicate. They were immersed in $1 \%$ lysing solution (2.5M NaCl, 100mM EDTA, 10mM buffer Tris-HCl, pH $10,1 \%$ sodium sarcosinate with $1 \%$ Triton X-100, 10\% DMSO) for 1 hour. After submission to electrophoresis (under alkaline buffer solution, $\mathrm{pH}>13$ ), they were fixed in absolute alcohol and stored until the moment of analysis. Samples were used for positive control and processed in vitro by hydrogen peroxide at $100 \mu \mathrm{M}$ for 5 minutes in ice (in triplicate) in order to ensure assay reproducibility and sensitivity. The slides were stained by $100 \mu \mathrm{l}$ of ethidium bromide $(2 \mu \mathrm{g} / \mathrm{ml})$ and analyzed on a fluorescence microscope (Olympus) connected to a camera with an imageanalysis system (Comet Assay II, Perceptive Instruments, Suffolk, Haverhill, UK) under a magnification of 400X. A total number of 50 cells (comets) per slide were analyzed ${ }^{4}$. Two parameters were taken into account in order to estimate DNA damage: tail moment (DNA product contained by the tail X florescence intensity) and the intensity of the comets' tail (\% of migrated DNA) ${ }^{4}$. The data were statistically analyzed by Analysis of Variance for one Criterion (ANOVA), and the Tukey's Test was used for individualization. $\mathrm{p}<0.05$ was considered to be statistically significant.

In this study, patients with active PCM (G1 - mean age: $41.38 \pm 13.89$ years) did not show DNA damage in peripheral blood cells (mean for the tail moment: 1.54 \pm 0.91 and mean

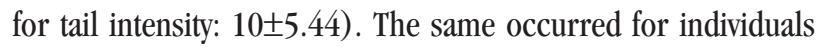
with PCM in clinical remission and positive serology by double immunodiffusion (G2 - mean age: $54.72 \pm 10.33$ years). This group also showed a tail moment mean of $0.96 \pm 0.66$ and a tail intensity mean of $7.24 \pm 5.13$. When compared to the control group (G3 - mean age: $46.3 \pm 16$ years; the tail-moment value: $1.14 \pm 0.97$ and tail intensity: 6.93 \pm 4.44$)$, the data did not show statistical difference $(\mathrm{p}=0.49)$.

These findings preliminarily suggest that PCM does not have genotoxic activity, although it was observed that the tail-moment and tail intensity values were higher for patients whose disease was active, lower for the healthy controls, and intermediate for those with apparent cure. A larger sample would provide a more conclusive analysis; nevertheless, that was not possible due to the high prevalence of smokers in the universe of patients with PCM $^{14}$. In this sense, in previous studies performed by the same group, the frequency of cells in metaphase with a premature centromere division was significantly higher in patients in the active phase of the disease than in those with clinical cure and positive serology, thus suggesting aneugenic action (induced aneuploidia) by Paracoccidioides brasiliensi ${ }^{3}$. The findings in his study are in disagreement with those investigating the genotoxic potential of some infectious diseases incident in our environment, such as leishmaniasis and toxoplasmosis ${ }^{71}$. Although it has, in the last few decades, been well established that genotoxicity is a classic mechanism and strong evidence of carcinogenicity, ${ }^{1}$ it has been noted that such condition is not a strictly linear process; that is, it is the result of genetic, epigenetic and phenotypic alterations in different biochemical and molecular levels ${ }^{10}$. Based on this premise and on our results, it can be assumed that any evidence of carcinogenicity attributed to PCM does not seem to stem from genotoxicity. Therefore, for more accurate judgment as regards genotoxicity, the use of other methodologies is recommended in order to elucidate the effect of Paracoccidioides brasiliensis on genetic material.

\section{REFERENCES}

1. Auletta A, AshbyJ. Workshop on the relationship between short-term information and carcinogenicity; Williamsburg, Virginia, January 20-23, 1987. Environmental and Molecular Mutagenesis 11:135-145, 1988.

2. Cadavid D, Restrepo A. Factors associated with Paracoccidiodes brasiliensis infection among permanent residents of three endemic areas in Colombia. Epidemiology and Infection 111:121-133, 1993.

3. Freire-Maia DV, Garcia MG, Mendes RP, Marques SA, Curi PR, Souza LR. Chromosome aberrations in lymphocyte cultures from paracoccidioidomycosis patients. Journal of Medical and Veterinary Mycology 32:199-203, 1994.

4. Hartmann A, Speit G. The contribution of cytotoxicity to DNA-effects in the single cell gel test (comet assay). Toxicology Letters 90:183-188, 1997.

5. Herrera LA, Ostrosky-Wegman P. Do helminths play a role in carcinogenesis? Trends in Parasitology 17:172-175, 2001.

6. International Agency for Research on Cancer (IARC). Working Group on the Evaluation of Carcinogenic Risks to Humans. Schistosomes, liver flukes and Helicobacter pylori. Lyon, 7-14 June 1994. IARC Monographs on the Evaluation of Carcinogenic Risks to Humans/World Health Organization, International Agency for Research on Cancer 61:1-241, 1994.

7. Kocyigit A, Keles H, Selek S, Guzel S, Celik H, Erel O. Increased DNA damage and oxidative stress in patients with cutaneous leishmaniasis. Mutation Research 585:71-78, 2005.

8. Marques SA, Franco MF, Mendes RP, Silva NC, Baccili C, Curcelli ED, Feracin AC, Oliveira CS, Tagliarini JV, Dillon NL. Epidemiologic aspects of paracoccidioidomycosis in the endemic area of Botucatu (São Paulo - Brazil). Revista do Instituto de Medicina Tropical de São Paulo 25:87-92, 1983.

9. Maymó Argañaraz M, Luque AG, Tosello ME, Perez J. Paracoccidioidomycosis and larynx carcinoma. Mycoses 46:229-232, 2003.

10. Nagpal JK, Das BR. Oral cancer: reviewing the present understanding of its molecular mechanism and exploring the future directions for its effective management. Oral Oncology 39:213-221, 2003. 
11. Ribeiro DA, Pereira PC, Machado JM, Silva SB, Pessoa AW, Salvadori DM. Does toxoplasmosis cause DNA damage? An evaluation in isogenic mice under normal diet or dietary restriction. Mutation Research 559:169-176, 2004.

12. Speit $\mathrm{G}$, Hartmann $\mathrm{A}$. The comet assay: a sensitive genotoxicity test for the detection of DNA damage. Methods in Molecular Biology 291:85-95, 2005.

13. Tice RR, Agurell E, Anderson D, Burlinson B, Hartmann A, Kobayashi H, Miyamae Y, Rojas E, Ryu JC, Sasaki YF. Single cell gel/comet assay: guidelines for in vitro and in vivo genetic toxicology testing. Environmental and Molecular Mutagenesis 35:206-221, 2000.

14. Verli FD, Marinho SA, Souza SC, Figueiredo MA, Yurgel LS. Clinical-epidemiologic profile of paracoccidioidomycosis at the Stomatology Department of São Lucas Hospital, Pontificia Universidade Católica do Rio Grande do Sul. Revista da Sociedade Brasileira de Medicina Tropical 38:234-237, 2005. 